\title{
Evaluación de productos de tratamiento para la portada de la iglesia de Santiago de Guadix
}

\author{
Evaluation of treatment products for the front door of the \\ church of Santiago, Guadix
}

Fecha de recepción: 26-VII-00

Fecha de aceptación: 21-IX-00

R.VILLEGAS-SÁNCHEZ, J. ESPINOSA GAITÁN
Instituto Andaluz del Patrimonio Histórico. Isla de la Cartuja, Sevilla

\section{RESUMEN \\ En un artículo anterior se han caracterizado los materiales y el estado de conservación de la Portada de la iglesia, con objeto de determinar las causas y los mecanismos de alteración que aparecen en la misma.}

En el presente trabajo se evalúa el comportamiento de diversos tratamientos, hidrófugos y/o consolidantes, para determinar su eficacia y su respuesta frente a los factores de alteración.

Para ello se han determinado las propiedades hidricas y mecánicas, y la resistencia a la alteración se ha valorado sometiendo las muestras tratadas a ensayos de alteración que reproducen los mecanismos de deterioro observados, la cristalización de sales y la heladicidad.

\section{SUMMARY \\ In a previous article the materials and the state of conservation of the Front Door of the church have been characterized, with the aim of determining the causes and the alteration mechanisms that are present in it. \\ In the present work the behaviour of several treatments, water repellents and/or consolidants, is evaluated to determine their effectiveness and their answer to the weathering factors.}

With this object, several characteristics of the stone, before and after the application of treatments, have been determined, as well as the weathering resistance that has been measured subjecting the samples to alteration tests that reproduce the observed weathering mechanisms, salt crystallization and freezing-thawing.

\section{INTRODUCCIÓN}

La Portada de la iglesia de Santiago de Guadix (Granada) atribuida a Diego de Siloe, está construida en una calcarenita procedente de la cantera de Bácor (Granada). La piedra está cubierta de una costra muy compacta de oxalato cálcico que, originalmente, posiblemente se extendería por toda la portada, pero que actualmente se ha desprendido casi por completo en las zonas bajas y presenta un picado muy extendido en el resto. También se han encontrado en las zonas más protegidas, restos de decoración pictórica (1). El factor de alteración más importante es la humedad de capilaridad, que ha provocado mecanismos de

\section{INTRODUCTION}

The Front Door of the church of Santiago, Guadix (Granada), attributed to Diego de Siloe, is built with a calcarenite coming from the quarry of Bácor (Granada). The stone is covered with a very compact crust of calcium oxalate that, originally, would possibly extend for the whole door, but that, nowadays, has fallen down almost completely in the lower areas, presenting a very extended pitting in the rest. There are also, in the protected areas, remains of pictorial decoration (1). The more important alteration factor is the rising damp that has gave origin to mechanisms of salt crystallization 
cristalización de sales y de heladicidad. Esto, junto con la presencia de la costra de oxalato, ha provocado la disgregación de la piedra debajo de dicha capa; en las zonas más bajas esta disgregación ha conducido a la eliminación de la costra y a grandes pérdidas de material, mientras que a mayor altura aparece el picado por desprendimiento de la costra en zonas puntuales.

Antes de llevar a cabo cualquier intervención de restauración de materiales pétreos es conveniente determinar la idoneidad de los posibles productos a utilizar mediante ensayos de laboratorio, de forma que el efecto de dichos productos, ya sea favorable o perjudicial, se ponga de manifiesto antes de su aplicación in situ. Tomando como punto de partida que en la intervención que se acometiese sería imprescindible eliminar la entrada de agua por capilaridad desde el subsuelo, se han estudiado diversos tratamientos consolidantes y/o hidrófugos para aumentar la cohesión de la piedra e impedir la entrada de agua desde la superficie.

En las probetas tratadas se han determinado diversas características, para determinar la eficacia de los tratamientos, y se han sometido a ensayos de alteración acelerada para estudiar la resistencia a los agentes de deterioro.

\section{APLICACIÓN DE LOS TRATAMIENTOS}

Para la realización de los distintos ensayos se han utilizado probetas cúbicas de $5 \mathrm{~cm}$, obtenidas en este caso de la cantera de Bácor, que ya había sido localizada (1). Antes de la impregnación con los productos, las probetas se han limpiado y dejado secar al aire, para conseguir un contenido de humedad higroscópica en equilibrio con el ambiente. Las probetas se han tratado por inmersión durante diez minutos, tiempo suficiente para conseguir una buena penetración. Los productos empleados aparecen en la Tabla 1.

Además de cada producto independiente algunas probetas tratadas con los consolidantes organosilícicos se han impregnado, después de la completa polimerización del silicato de etilo, con el hidrófugo del mismo fabricante, es decir, las combinaciones han sido:

Tegovakon + Tegosivin HL 100

Consolidante $\mathrm{OH}+\mathrm{BS} 28$

Tras la impregnación se ha controlado la evolución de peso de las probetas hasta el completo secado de los tratamientos. De esta forma se ha determinado el tiempo de secado, el incremento de peso $y$, and ice formation. This fact, together with the presence of the oxalate crust, has caused the disintegration of the stone under this layer; in the lowest areas this disintegration has led to the elimination of the crust and important material losses, while at bigger height the pitting due to the detachment of the crust in punctual areas appears.

Before carrying out any restoration intervention on stony materials, it is convinient to determine the suitability of the products to be used by means of laboratory tests, so that the effect of these products, either favorable or harmful, manifests before their application in situ. Taking as starting point that to eliminate the entrance of water for capillarity from the ground would be indispensable, several treatments (consolidants and/or water repellents) have been studied, with the aim of getting an improvement on the cohesion of the stone and avoiding the entrance of water from the surface.

Several characteristics have been determined In the treated samples, to determine the effectiveness of the treatments, and they have been submitted to accelerated weathering tests to study their resistance to the weathering agents.

\section{APPLICATION OF THE TREATMENTS}

To carry out the tests cubic samples of $5 \mathrm{~cm}$ have been used, obtained in this case from the quarry of Bácor that had already been located (1). Before the impregnation with the products, the samples have been cleaned and let to dry to the air, to get a content of hygroscopic humidity in equilibrium with the ambient. The samples have been treated by immersion during ten minutes, time enough to get a good penetration. The products used appear in Table 1.

Besides each treatment alone, some samples treated with the organosilicic consolidants have been impregnated, after the complete polymerization of the ethyl silicate, with the corresponding water repellents, that is to say, the combinations have been:

\section{Tegovakon + Tegosivin HL 100}

Strengthener $\mathrm{OH}+\mathrm{BS} 28$

After the impregnation the evolution of weight of the samples has been controlled until the complete drying of the treatments. So, the drying time and the increment of weight have been determined and 
posteriormente, se ha medido la variación de porosidad. En la Figura 1 aparecen las curvas de evolución media de peso durante el secado de los tratamientos.

Los dos consolidantes organosilícicos tardan 15-20 días en secarse por completo, ya que estos productos se aplican en forma de monómeros y deben polimerizar en la piedra.

El producto acrilsilicónico, que se aplica en forma de polímero, se seca en un plazo muy corto, 1-2 días, ya que sólo debe tener lugar la evaporación del disolvente. Lo mismo sucede con el producto acrílico, que se aplica como polímero. Los hidrófugos organosilícicos tardan aproximadamente 15 días en completar el proceso. afterwards the porosity variation has been measured. The average weight evolutions appear on Figure 1.

The two organosilicic consolidants take 15-20 days in drying off completely, since these products are applied in monomeric form and they have to polymerize inside the stone.

The acrylsiliconic product, that is applied in polymeric form, dries off in a very short term, 1-2 days, since only the evaporation of the solvent takes place. The same thing happens to the acrylic product that is also applied as polymer. The organosilicic water-repellents take approximately 15 days in completing the process.

TABLA 1/TABLE 1

Características de los tratamientos/Treatments characteristics

\begin{tabular}{|l|l|l|l|}
\hline $\begin{array}{l}\text { Producto } \\
\text { Treatment }\end{array}$ & $\begin{array}{l}\text { Fabricante } \\
\text { Manufacturer }\end{array}$ & $\begin{array}{l}\text { Composición } \\
\text { Composition }\end{array}$ & $\begin{array}{l}\text { Aplicación } \\
\text { Application }\end{array}$ \\
\hline Tegovakon & Goldschmidt & $\begin{array}{l}\text { Silicato de etilo } \\
\text { Ethyl silicate }\end{array}$ & $\begin{array}{l}\text { Disuelto al 50\% } \\
\text { Diluted to 50\% }\end{array}$ \\
\hline Tegosivin HL 100 & Goldschmidt & $\begin{array}{l}\text { Organosilícico polímero } \\
\text { Monomeric organosilicic }\end{array}$ & $\begin{array}{l}\text { Al 5\% en Xileno } \\
5 \% \text { in Xylen }\end{array}$ \\
\hline Consolidante OH & Wacker & $\begin{array}{l}\text { Silicato de etilo } \\
\text { Ethyl silicate }\end{array}$ & $\begin{array}{l}\text { Disuelto al 50\% } \\
\text { Diluted to 50\% }\end{array}$ \\
\hline BS 28 & Wacker & $\begin{array}{l}\text { Organosilicico } \\
\text { Organosilicic }\end{array}$ & $\begin{array}{l}\text { Disuelto al 5\% } \\
\text { Diluted to 5\% }\end{array}$ \\
\hline ARD 55050 & ARD RAccanello & $\begin{array}{l}\text { Resina acrilsilicónica } \\
\text { Acrylsiliconic resin }\end{array}$ & $\begin{array}{l}\text { Disuelto al 10\% } \\
\text { Diluted to 10\% }\end{array}$ \\
\hline Paraloid B72 & Rohm \& Haas & $\begin{array}{l}\text { Copolimero de metacrilato } \\
\text { yetilmetacrilato } \\
\text { Metacrylate- } \\
\text { ethylmetacrilate }\end{array}$ & $\begin{array}{l}\text { Al 10 \% en xileno } \\
10 \% \text { in Xylen }\end{array}$ \\
\hline
\end{tabular}

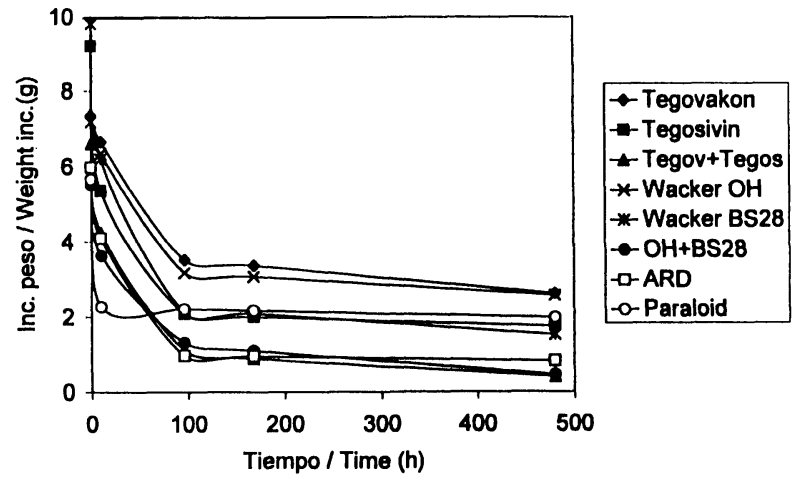

Figura 1.- Secado de los tratamientos/ Figure 1.- Drying of treatments 
Los incrementos de peso experimentados por las probetas son proporcionales a los contenidos de materia activa de los tratamientos. Los dos organosilícicos son bastante más concentrados, si bien parte del producto se evapora en forma de etanol al polimerizar. Por ello, en estos dos casos, los incrementos de peso son mayores. El resto de los productos, que se aplican en una concentración mayor, producen incrementos de peso más bajos.

\section{EVALUACIÓN DE TRATAMIENTOS. RESULTADOS}

Para evaluar los tratamientos y seleccionar el (los) más adecuado(s) se ha seguido la metodología puesta a punto en el I. A. P. H., consistente en estudiar tres aspectos:

- Compatibilidad del tratamiento con el material

- Eficacia del tratamiento

- Resistencia de la piedra tratada a la alteración

\subsection{Compatibilidad con el material}

Para determinar si un tratamiento es aceptable, es fundamental conocer cómo modifica algunas características del material. Entre ellas son muy importantes la porosidad, la velocidad de evaporación de agua y el color. Si la variación producida es excesivamente alta, puede ser necesario descartar dicho tratamiento.

\subsubsection{Porosidad}

La determinación de la porosidad abierta se ha realizado por el método de absorción de agua a vacío (2).

La porosidad se ha determinado en las probetas antes y después del tratamiento y los valores medios aparecen en la Tabla 2. También se indica la disminución media de la porosidad para cada tratamiento.

La disminución de porosidad es más baja con los acrílicos, ya que se aplican en concentraciones menores. Con los consolidantes organosilícicos se obtienen valores similares y con los hidrófugos organosilícicos se producen las mayores variaciones. En principio, no es deseable que se produzca una disminución muy acusada de la porosidad.

\subsubsection{Velocidad de desorción de agua}

La velocidad de desorción de agua se determina según el siguiente procedimiento:
The weight increments of the samples are proportional to the contents of active matter of the treatments. The two organosiliic consolidants are quite concentrated, although a part of the product evaporates in form of ethanol when polimerization occurs. Because of it, in these two cases the weight increments are bigger. The rest of the products that are applied in lower concentrations, produces lower increments of weight. In the Figure 1 the curves of evolution of weight during the drying of the treatments are represented.

\section{EVALUATION OF TREATMENTS. RESULTS}

To evaluate the treatments and to select those more adecuated the methodology prepared in the I. A. P. H. has been followed, studying three aspects:

- Compatibility of the treatment with the material

- Effectiveness of the treatment

- Resistance of the treated stone to weathering

\subsection{Compatibility with the material}

To determine if a treatment is acceptable, it is fundamental to know how it modifies some characteristics of the material. Among them the porosity, the water evaporation rate and the colour are very important. If the variation caused is excessively high, it could be necessary to discard the treatment.

\subsubsection{Porosity}

The determination of the open porosity has been carried out for the method of vacuum water absorption (2).

The porosity has been determined in the samples before and after the application of the treatments and the average values appear in the Table 2. The average decrease of the porosity is also indicated for each treatment.

The porosity decrement is lower with the acrylic ones, since they are applied in smaller concentrations. With the organosilicic consolidants similar values are obtained and with the organosilicic water repellents the biggest variations take place. In principle, it is not desirable that a very high decrease of the porosity takes place.

\subsubsection{Water desorption rate}

The water desorption rate is determined according to the following procedure: 
TABLA 2/TABLE 2

Porosidad media (\%), con y sin tratamiento/Average porosity (\%), before and after treatment

\begin{tabular}{|l|c|c|}
\hline $\begin{array}{l}\text { Tratamiento } \\
\text { Treatment }\end{array}$ & $\begin{array}{l}\text { Porosidad antes / después } \\
\text { Porosity before / after }\end{array}$ & $\begin{array}{l}\text { Disminución de porosidad } \\
\text { Porosity decrease }\end{array}$ \\
\hline Sin tratar / Untreated & 22.04 & 1.02 \\
\hline Tegovakon & $22.26 / 21.24$ & 1.87 \\
\hline Tegosivin HL 100 & $22.17 / 20.30$ & 0.89 \\
\hline Consolidante OH & $21.69 / 20.83$ & 1.35 \\
\hline BS 28 & $21.69 / 20.34$ & 0.51 \\
\hline ARD 55050 & $22.05 / 21.54$ & 0.40 \\
\hline Paraloid B72 & $22.51 / 22.11$ & \\
\hline
\end{tabular}

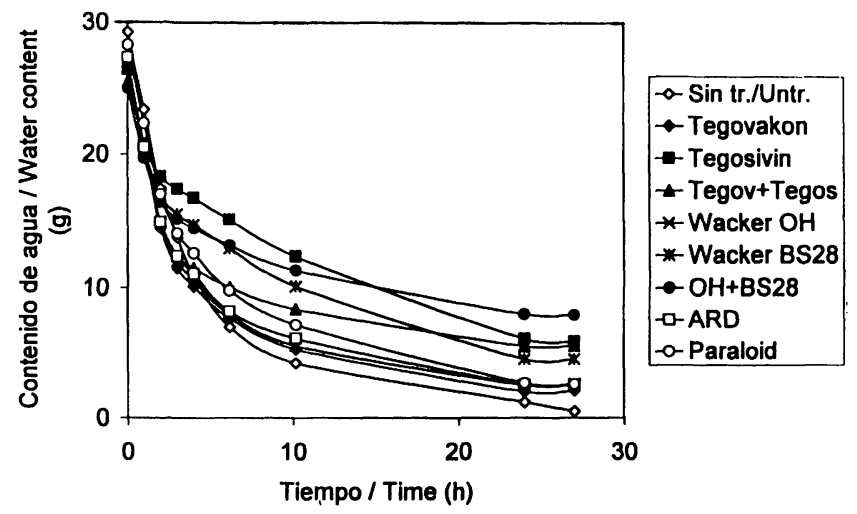

Figura 2.- Desorción de agua/Figure 2.- Water desorption

- se saturan las probetas de agua por inmersión

a vacío

- se colocan en atmósfera controlada a $20^{\circ} \mathrm{C}$ y $50 \%$ de HR

- se pesan periódicamente hasta peso constante

De esta forma se mide la velocidad inicial de evaporación de agua y el contenido residual de agua que queda en la piedra, el contenido crítico. Las curvas de secado aparecen en la Figura 2 y en la Tabla 3 se recogen los valores antes mencionados.

Se observa que la velocidad de evaporación prácticamente no cambia con Consolidante $\mathrm{OH}$, Tegovakon, ARD y Paraloid, mientras que disminuye considerablemente con los dos hidrófugos organosilícicos, solos o con los consolidantes. Algo semejante ocurre con el contenido crítico, dichos hidrófugos producen un aumento apreciable y los restantes no causan ninguna variación.

Estos dos efectos no son deseables, por cuanto hacen que la piedra se mantenga más húmeda durante más
- the samples are saturated of water by vacuum water absorption

- they are placed in controlled atmosphere with $20{ }^{\circ} \mathrm{C}$ and $50 \%$ of $R H$

- they are weighed periodically until constant weight

In this way, the initial rate of water evaporation can be calculated as well as the residual content of water that remains in the stone, the critical content. The drying curves appear in the Figure 2 and in the Table 3 the values above mentioned.

It is observed that the evaporation rate practically doesn't change with Strengthener OH, Tegovakon, ARD and Paraloid, while it diminishes considerably with the two organosilicic water repellents, alone or with the consolidants. Something similar happens with the critical content, these water repellents produce an appreciable increase and the rest doesn't cause any variation.

These two effects are not desirable, since they make that the stone remains more wet for a longer time, 
TABLA 3/TABLE 3

Desorción de agua/Water desorption

\begin{tabular}{|l|c|c|}
\hline $\begin{array}{l}\text { Tratamiento } \\
\text { Treatment }\end{array}$ & $\begin{array}{c}\text { Velocidad inicial }\left(\mathbf{m g} / \mathbf{c m}^{2} \cdot \mathbf{h}\right) \\
\text { Initial rate }\end{array}$ & $\begin{array}{c}\text { Contenido crítico }\left(\mathbf{m g} / \mathbf{c m}^{\mathbf{3}}\right) \\
\text { Critical water content }\end{array}$ \\
\hline Sin tratar / Untreated & 39.4 & 20 \\
\hline Tegovakon & 42.1 & 16 \\
\hline Tegosivin HL 100 & 26.8 & 48 \\
\hline Tegov.+ Tegosiv. & 35.2 & 45 \\
\hline Consolidante OH & 39.3 & 20 \\
\hline BS 28 & 31.1 & 36 \\
\hline Cons. OH + BS 28 & 28.5 & 64 \\
\hline ARD 55050 & 41.3 & 20 \\
\hline Paraloid B72 & 37.6 & 21 \\
\hline
\end{tabular}

TABLA 4/TABLE 4

Color (coordenadas CIE)/Colour (CIE coordinate)

\begin{tabular}{|l|c|c|c|}
\hline $\begin{array}{l}\text { Tratamiento } \\
\text { Treatment }\end{array}$ & $\mathrm{Y}$ & $\mathrm{x}$ & $\mathrm{y}$ \\
\hline Sin tratar/ Untreated & 37.06 & 0.3554 & 0.3662 \\
\hline Tegovakon & 37.48 & 0.3518 & 0.3627 \\
\hline Tegosivin HL100 & 36.11 & 0.3545 & 0.3648 \\
\hline Consolidante OH & 40.20 & 0.3475 & 0.3615 \\
\hline BS 28 & 37.06 & 0.3532 & 0.3647 \\
\hline ARD 55050 & 32.04 & 0.3563 & 0.3676 \\
\hline Paraloid B72 & 26.31 & 0.3659 & 0.3707 \\
\hline
\end{tabular}

tiempo, es decir, tarda más en secarse, con lo que todos los mecanismos de alteración relacionados con el agua se ven favorecidos.

\subsubsection{Color}

Se ha medido el color de probetas, tratadas y sin tratar, con un colorímetro Minolta. Los datos

correspondientes a las coordenadas CIE aparecen en la Tabla 4. El primer valor, $Y$, es una medida de la claridad del color (valor más alto corresponde a un color más claro). Los siguientes valores, $\mathrm{x}$ e $\mathrm{y}$, son coordenadas que representan el tono o color. that is to say, it takes more time in drying off; so, all the alteration mechanisms related to water are favoured.

\subsubsection{Colour}

The colour of treated and untreated samples has been measured with a Minolta colorimeter. The data corresponding to the CIE coordinate appear in the Table 4. The first value, $Y$, is a measure of the clarity of the colour (higher value corresponds to a clearer colour). The following values, $x$ and $y$, are coordinates that represent the tone or colour. 
Se observa que todas las probetas se encuentran en la misma zona cromática (valores de x e y muy semejantes), pero, en algunos casos, ARD y Paraloid, se produce un oscurecimiento significativo.

\subsection{Eficacia del tratamiento}

Cuando se aplica un tratamiento se pretende conseguir una mejora en determinadas características. En el caso de los productos hidrófugos se trata de disminuir la entrada de agua en la piedra y en el caso de los consolidantes aumentar la cohesión del material. Para evaluar esta mejora se determina, en el primer caso, cómo se modifica la absorción de agua y, en el segundo, se miden las propiedades mecánicas.

\subsubsection{Absorción de agua por capilaridad}

La determinación de la absorción de agua por capilaridad se ha realizado siguiendo la RECOMANDAZIONE NORMAL (3). En la Figura 3 se representa la absorción media de agua para cada tratamiento.

Los valores correspondientes a las probetas tratadas con los consolidantes organosilícicos son muy semejantes a los de las no tratadas, con disminuciones muy pequeñas debidas a la disminución de porosidad provocada por los tratamientos. La aplicación de los hidrófugos organosilícicos produce una apreciable reducción en la absorción, de forma muy parecida cuando se aplican con o sin el consolidante. Los productos acrílicos presentan un comportamiento aceptable.

\subsubsection{Absorción de agua por inmersión}

La determinación de la absorción de agua por inmersión se ha realizado siguiendo la RECOMANDAZIONE NORMAL (4).

En la Figura 4 se representan los valores medios de absorción de cada tratamiento y sin tratar, y de una
It is observed that all the samples are in the same chromatic area (values of $x$ and and very similar), but in some cases, ARD and Paraloid, a significant obscuring takes place.

\subsection{Effectiveness of the treatment}

Treatments are applied with the object of getting an improvement in certain characteristic. In the case of the water repellent products, to diminish the entrance of water in the stone; in the case of the consolidants, to increase the cohesion of the material. To evaluate this improvement, how the absorption of water is modified has been determined, in the first case, and, in the second, the mechanical properties.

\subsubsection{Absorption of water by capillarity}

The determination of the absorption of water by capillarity has been carried out following the RECOMANDAZIONE NORMALE (3). In the Figure 3 the average values of water absorption are represented.

The values corresponding to the samples treated with the organosilicic consolidants are very similar to those of non treated ones, little lesser due to the decrease of porosity caused by the treatments. The application of the organosilicic water repellents produces an appreciable reduction in the absorption, in a very similar way when they are applied with or without the consolidant. Acrylic products present an acceptable behaviour.

\subsubsection{Immersion water absorption}

The determination of the immersion water absorption has been carried out following the RECOMANDAZIONE NORMALE (4).

In the Figure 4 the average values of absorption are represented for the samples treated with each

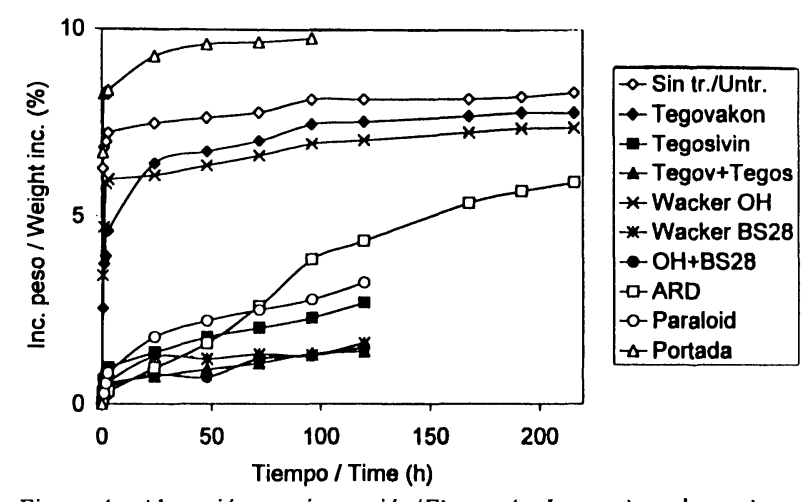

Figura 4.- Absorción por inmersión/Figure 4.- Immersion absorption 
muestra de la Portada que fue sometida al mismo ensayo.

En este ensayo el contacto con el agua es mucho más intenso que en el de capilaridad, por lo que hay menos diferencia en los contenidos de agua de las probetas tratadas y sin tratar. Se aprecia que se mantiene bastante bien el efecto hidrófugo de los dos productos organosilícicos, mientras que los acrílicos reducen bastante menos la absorción. En el caso de Tegosivin HL 100 la aplicación con el consolidante mejora bastante el efecto hidrófugo.

También se observa que la absorción de la muestra de la portada (la cual se disgregó en parte a las 96 horas) es mayor que en las probetas de piedra sin alterar, lo cual es indicativo de su grado de alteración.

\subsubsection{Dureza superficial}

Para determinar el efecto de la mejora en la cohesión del material se determinan las propiedades mecánicas, ya sean globales -resistencia a la compresión o flexión, fundamentalmente- o superficiales. En este caso se ha preferido esta última, ya que el efecto de los tratamientos normalmente se manifiesta en una capa superficial.

La medida de la dureza superficial que se ha realizado se basa en la resistencia que opone un material a ser penetrado por un cuerpo más duro. La dureza de las probetas tratadas y sin tratar se ha medido con un durómetro tipo Rockwell, empleando una bola de $5 \mathrm{~mm}$, aplicando una precarga de $10 \mathrm{~kg}$ y una carga total de $30 \mathrm{~kg}$. El valor de la dureza se determina como función inversa de la diferencia entre la penetración de la bola con la carga de $30 \mathrm{~kg}$ y con la carga de $10 \mathrm{~kg}$. En cada probeta se han realizado 9 medidas en cada una de las tres caras que confluyen en un vértice, en total 27 medidas. Se ha determinado solamente para los consolidantes.

En la Figura 5 se ha representado el incremento medio de la dureza con cada tratamiento respecto a las probetas sin tratar. product and untreated, as well as a sample of the Door.

In this test the contact with the water is much more intense, for what the differences between the contents of water of the treated and the untreated samples are smaller. It could be noticed that the hydrophobic effect remains quite well for the two organosilicic products, while the acrylic ones reduce quite less the absorption. In the case of Tegosivin HL 100 the application with the consolidant improves significantly the hydrophobic effect.

It is also observed that the absorption of the sample of the Door (which disintegrated partly at the 96 hours) is bigger than for the unweathered samples, which is indicative of its alteration degree.

\subsubsection{Superficial hardness}

To determine the effect of the improvement in the cohesion of the material, the mechanical properties are determined, either global or superficial. In this case, this last one has been preferred, since the effect of the treatments is usually manifested in a superficial layer.

The measurement of the superficial hardness that has been carried out is based on the resistance that a material opposes to be penetrated by a harder body. The hardness of the treated and untreated samples has been measured following Rockwell procedure, using a ball of $5 \mathrm{~mm}$, applying a precharge of $10 \mathrm{~kg}$ and a total load of $30 \mathrm{~kg}$. The value of the hardness is determined as inverse function of the difference among the penetration of the ball with the load of 30 $\mathrm{kg}$ and with the load of $10 \mathrm{~kg}$. In each sample 9 measures have been carried out in three perpendicular faces, in total 27 measures. It has only been determined for the consolidated samples.

In the Figure 5 the average hardness increment has been represented for each treatment with respect to the untreated samples.

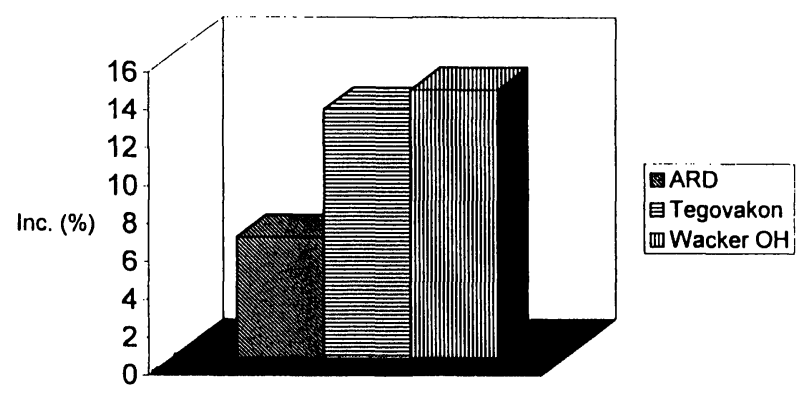

Figura 5.- Incremento de dureza/Figure 5.- Hardness increment 
Como se observa, los tratamientos que más aumentan la dureza superficial de la piedra respecto a las probetas sin tratar son Consolidante $\mathrm{OH}$ y Tegovakon; éstas son las que han experimentado mayor incremento de peso con el tratamiento y mayor disminución de la porosidad.

\subsection{Resistencia a la alteración. Ensayos de alteración acelerada}

El último paso en la evaluación de los tratamientos consiste en someter las probetas a condiciones que simulen los mecanismos de alteración observados en el edificio, pero de forma concentrada en el tiempo, para obtener resultados en plazos más breves. En este caso uno de dichos mecanismos es la cristalización de las sales presentes en la piedra, procedentes bien de morteros o bien de la propia piedra, que ya, en cantera, muestra un contenido en yeso apreciable.

Otro mecanismo es la formación de hielo en el interior de la piedra, cuando la temperatura desciende por debajo de $0{ }^{\circ} \mathrm{C}$, lo cual ocurre en Guadix con relativa frecuencia.

Por ello, los ensayos de alteración acelerada que mejor reproducen dichos mecanismos de alteración son el de cristalización de sales y el de hielo-deshiclo.

\subsubsection{Ensayo de cristalización de sales}

Este ensayo consiste en someter a las probetas a cristalizaciones y solubilizaciones sucesivas de una sal soluble. En este caso se ha utilizado una solución de sulfato de sodio al $10 \%(\mathrm{p} / \mathrm{v})$ y se han realizado ciclos formados por las siguientes fases:

- Fase de inmersión: 24 horas de inmersión - Fase de secado: 22 horas de secado a $65^{\circ} \mathrm{C}, 2$ horas de enfriamiento y pesada

Se ha llevado a cabo con tres probetas de cada tipo, sin tratar y tratadas con cada producto. A lo largo del ensayo se efectúa el control del peso de las probetas en cada ciclo y de las alteraciones macroscópicas que van apareciendo. Cuando el grado de deterioro alcanzado por una probeta es grande se elimina del ensayo.

En la Figura 6 se representa la evolución de pesos medios para cada tratamiento a lo largo del ensayo, expresada en $\%$ respecto al peso original.

Las probetas sin tratar comienzan a absorber solución desde el primer ciclo, lo cual se manifiesta en un ligero incremento de peso; a continuación empiezan a desprenderse granos de la superficie, uniformemente por toda ella, hasta que la pérdida de materia es elevada y se da por finalizado el ensayo.
As it could be observed, the treatments that produce a higher increments on the superficial hardness are Strengthener $\mathrm{OH}$ and Tegovakon; these are those that have produced bigger increments of weight and bigger decreases of the porosity.

\subsection{Weathering resistance. Accelerated weathering tests}

The last step in the evaluation of the treatments consists on subjecting the samples to conditions that simulate the alteration mechanisms observed in the building, but in a concentrated way in time, to obtain results in briefer terms. In this case one of this mechanisms is the crystallization of the salts present in the stone, coming either from mortars or from the stone itself that, already in quarry, shows an appreciable content of gypsum.

Another mechanism is freezing inside the stone, when the temperature descends below $0{ }^{\circ} \mathrm{C}$, which happens in Guadix quite frequently.

So that, the accelerated weathering tests that better reproduce these alteration mechanisms are that of salt crystallization and that of freeze-thaw.

\subsubsection{Salt crystallization test}

This test consists on subjecting the samples to crystallization and successive disollution of a soluble salt. In this case a $10 \%$ sodium sulfate solution has been used and cycles formed by the following phases have been carried out:

- Immersion phase: 24 hours of immersion

- Drying phase: 22 hours of drying at $65^{\circ} \mathrm{C}, 2$ hours of cooling and weighing

It has been carried out with three samples of each type, untreated and treated with each product. The control of the weight of the samples is made in each cycle as well as the macroscopic alterations that appear. When the degree of deterioration reached by a sample is high it is eliminated of the test.

In the Figure 6 the average weight evolution (weight increment \%) is represented for each treatment along the test.

The untreated samples begin to absorb solution since the first cycle, which is manifested in a slight increment of weight; next they begin to loose grains of the surface, until the loss of material is high and the samples finish the test. 


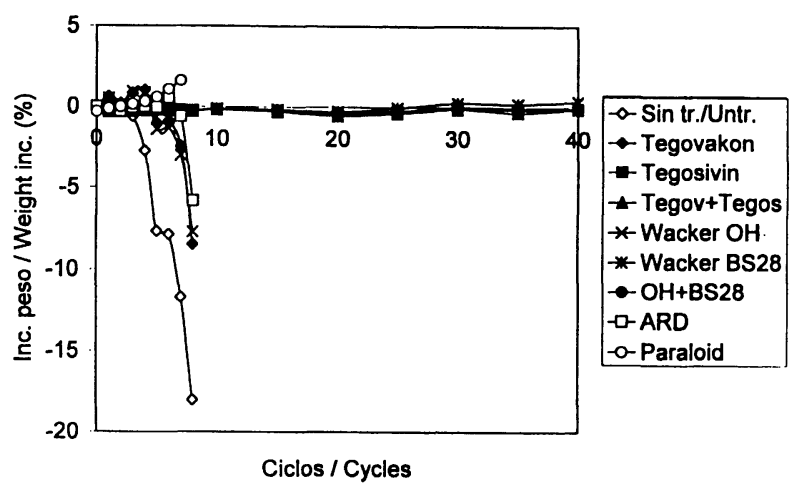

Figura 6.- Ensayo de cristalización de sales/Figure 6.- Salt crystallization test

Las probetas tratadas con los consolidantes organosilícicos solos tienen un comportamiento muy similar a las no tratadas, con menores pérdidas de peso, lo cual es indicativo de una mayor resistencia a la alteración, especialmente en el caso de Consolidante $\mathrm{OH}$, si bien la pequeña mejora que se obtiene no justificaría la aplicación de un tratamiento si no se elimina la entrada de agua por capilaridad desde el suelo.

Las probetas tratadas con los hidrófugos organosilícicos -solos o con los consolidantesresisten un número muy elevado de ciclos sin alterarse, lo cual indica que sus propiedades hidrófugas se mantienen sin cambio.

Las probetas tratadas con los productos acrílicos muestran un comportamiento semejante entre sí: tras resistir sin alteración aparente un número variable de ciclos, comienzan a ganar peso (se pierde el efecto hidrófugo y absorben solución) y la cristalización del sulfato que tiene lugar detrás de la capa tratada provoca la separación y desprendimiento de la misma.

\subsubsection{Ensayo de heladicidad}

Este ensayo consiste en someter a las probetas a ciclos formados por fases alternas de congelación y descongelación, con una fase previa de saturación por inmersión en agua. Estos ciclos son:

- Fase de congelación: 20 horas en cámara climática a $-20^{\circ} \mathrm{C}$

- Fase de descongelación: 4 horas de inmersión en agua a temperatura ambiente.

Se han realizado 50 ciclos y no se ha detectado la aparición de alteraciones macroscópicas ni pérdida de peso, hecho ya observado en otros ensayos similares (5).
The samples treated with the organosilicic consolidants have a very similar behaviour to those non treated, with smaller losses of weight, which is indicative of a bigger resistance to the alteration, especially in the case of Strengthener $\mathrm{OH}$, although the small improvement that is obtained does not justify the application of a treatment if the entrance of water by capillarity from the ground is not eliminated.

The samples treated with the organosilicic water repellents -alone or with the consolidants-resist a very high number of cycles without losing material, which indicates that their hydrophobic properties remain without change.

The samples treated with the two acrylic products show a similar behaviour between them: after resisting without visible alteration a variable number of cycles, they begin to win weight (the treatments loose their hydrophobic effect and they absorb solution) and the crystallization of the sulfate that takes place behind the treated layer causes the separation and detachment of this superficial layer.

\subsubsection{Freezing-thawing test}

This test consists on subjecting the samples to cycles formed by alternating phases of freezing and thawing, with a previous phase of saturation by immersion in water. These cycles are:

- Freezing phase: 20 hours in climatic chamber at $-20{ }^{\circ} \mathrm{C}$

\section{- Thawing phase: 4 hours of immersion in water to ambient temperature.}

They have been carried out 50 cycles and it has not been detected the aparison of macroscopic alterations neither loss of weight, the same fact that has been observed in other similar tests (5). 
Para tener otro elemento de juicio a fin de evaluar el comportamiento de los productos se han determinado las propiedades hídricas -absorción de agua por capilaridad y por inmersión- después del ensayo, datos que aparecen en las Figuras 7 y 8 . En la Tabla 5 aparecen los contenidos de agua máximos en ambos ensayos antes y después de la alteración.

En ambos ensayos se aprecia un aumento considerable de absorción en las probetas tratadas con ARD y Paraloid, llegándose a valores sólo ligeramente inferiores a los de las probetas sin tratar, es decir, pierden casi por completo su efecto hidrófugo. En las tratadas con Tegosivin HL 100 junto con Tegovakon se
To have another element to evaluate the behaviour of the products the hydric properties -absorption of water by capillarity and by immersion - have been determined after the test; this data are shown in the Figures 7 and 8. In the Table 5 the maximum water contents appear, both before and after the alteration.

In both measurements a considerable increase of absorption is appreciated in the samples treated with $A R D$ and Paraloid, with values only slightly inferior to those of the untreated samples, that is to say, they lose their hydrophobic effect almost completely. In those treated with Tegosivin HL 100 together with

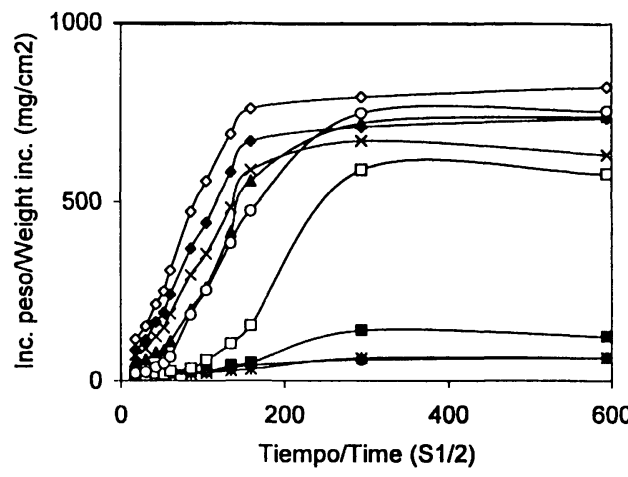

Figura 7.- Absorción capilar tras heladicidad.

Figure 7.- Capillarity absorption after freezing-thawing.

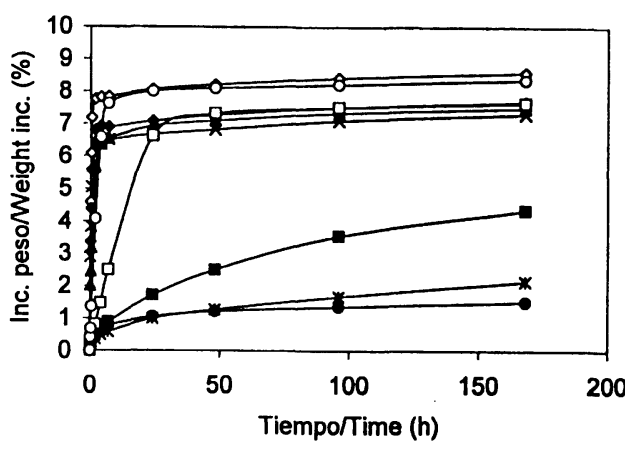

$\infty$ Sin tr./Untr. $\rightarrow$ Tegovakon

- Tegosivin

- Tegov+Tegos

* Wacker $\mathrm{OH}$

* Wacker BS28

$\rightarrow$ OH+BS28

- ARD

-o-Paraloid

Figura 8.- Absorción por inmersión tras heladicidad.

Figure 8.- Immersion absorption after freezing-thawing.

TABLA 5/TABLE 5

Absorción de agua antes y después de la alteración por hielo

(Colour/Water absorption before and after freezing thawing test)

\begin{tabular}{|c|c|c|c|c|}
\hline Tratamiento & $\begin{array}{c}\text { Capilaridad } \\
\text { Capillarity }\end{array}$ & $\left(\mathrm{mg} / \mathrm{cm}^{2}\right)$ & $\begin{array}{l}\text { Inmersión } \\
\text { Inmersion }\end{array}$ & (g) \\
\hline Treatment & $\begin{array}{l}\text { antes } \\
\text { before }\end{array}$ & $\begin{array}{l}\text { después } \\
\text { after }\end{array}$ & $\begin{array}{l}\text { antes } \\
\text { before }\end{array}$ & $\begin{array}{l}\text { después } \\
\text { after }\end{array}$ \\
\hline Sin tratar / Untr. & 788 & 821 & 8.14 & 8.60 \\
\hline Tegovakon & 764 & 732 & 7.70 & 7.69 \\
\hline Tegosivin HL100 & 100 & 124 & 2.67 & 4.35 \\
\hline Tegov.+Tegos. & 96 & 738 & 1.37 & 7.50 \\
\hline Consolidante $\mathrm{OH}$ & 672 & 630 & 7.27 & 7.31 \\
\hline BS 28 & 77 & 65.2 & 1.59 & 2.15 \\
\hline Cons. OH+ BS 28 & 78 & 64 & 1.48 & 1.52 \\
\hline ARD 55050 & 85 & 576.4 & 5.35 & 7.65 \\
\hline Paraloid B72 & 132 & 754 & 3.22 & 8.37 \\
\hline
\end{tabular}


produce también un incremento considerable, mientras que en las tratadas sólo con el hidrófugo el incremento observado es menor y se manifiesta más claramente en el ensayo de absorción por inmersión. El otro hidrófugo, BS 28, no sufre ninguna variación significativa después de la alteración.

\section{CONCLUSIONES}

La metodología seguida en el I. A. P. H. para evaluar el comportamiento de los tratamientos permite seleccionar el más apropiado para cada piedra y condiciones externas.

En el caso de la iglesia de Santiago, el tratamiento más aconsejable sería la combinación de Consolidante $\mathrm{OH}$ con BS 28, ya que solamente con la aplicación del consolidante no se consigue una mejora apreciable en la resistencia a la alteración. Sin embargo, el principal factor de alteración, el agua de capilaridad, seguiría actuando, ya que la aplicación de un tratamiento en la superficie externa no conseguiría frenar su entrada en absoluto. Es más, teniendo en cuenta las modificaciones que producen los tratamientos en el proceso de secado de la piedra, si no se elimina con total garantía esta entrada de agua del subsuelo, sería preferible no aplicar ningún tratamiento, ya que sería incluso contraproducente.
Tegovakon a considerable increment takes place too, while in those treated only with Tegosivin the increment observed is smaller and it is manifested more clearly in the measurement of absorption by immersion. The other water repellent, BS 28, doesn't suffer any significant variation after the alteration test.

\section{CONCLUSIONS}

The methodology followed in the I. A. P. H. to evaluate the behaviour of treatments allows to select the most appropriate one for each stone and the external conditions.

In the case of the Santiago church, the most advisable treatment would be the combination of Strengthener $\mathrm{OH}$ with $\mathrm{BS} 28$, since only with the application of the consolidant an appreciable improvement in the weathering resistance is not obtained. However, the main alteration factor, the rising damp, would continue acting, since the application of a treatment in the external surface would not be able to avoid its entrance. In addition, keeping in mind the modifications that the treatments produce in the process of water evaporation from the stone, if this entrance of water from the ground is not eliminated with total guarantee, it would be preferable not to apply any treatment.

\section{BIBLIOGRAFÍA}

(1) Espinosa, J.; Gutierrez, F.; Villegas, R.: Estudio analítico de la Portada de Santiago de Guadix (Granada). Materiales de Construcción, Vol.45, n² 238, pp 5-18, 1995.

(2)Van Keulen, H.: Determination of maximun water content. Report n. BI-72-39. Junio, 1972.

(3) NORMAL 11/85; Assorbimento d'aqua per capillaritá. Coefficiente di assorbimento capillare. C. N. R. - I. C. R., Roma, 1985.

(4) NORMAL 7/81. Assorbimento d'aqua per immersione totale. Capacité di imbibizione. C. N. R. - I. C. R., Roma, 1981.

(5) Villegas Sánchez, R.; Espinosa Gaitán, J.; Alcalde Moreno, M.: Study of weathering factors and evaluation of treatments for the stones of Santa María de la Encarnación Church, Constantina (Sevilla, Spain). Proc. 9th Int. Cong. on deterioration and conservation of stone. 697 705. Venice, June, 2000. 